\title{
Keunikan Perayaan Maulid Nabi di Tegal
}

\author{
Fathurozi \\ Staf Balai Penelitian dan Pengembangan Agama Semarang
}

Michael H. Hart (1978) dalam bukunya yang berjudul "Seratus Tokoh yang Paling Berpengaruh dalam Sejarah". Dia menempatkan nabi Muhammad saw pada urutan pertama, lalu posisi kedua Isaac Newton (Fisikawan), kemudian ururtan ke tiga Yesus/Nabi Isa. Mungkin penempatan ini sudah melalui tahapan pengajian mendalam.

Tak heran jika Muhammad saw sangat diidolakan pengikutnya. Umat Islam selalu melaksanakan apa yang diberbuat Nabi hingga sekarang masih langgen laksanakan di seantero nusantara. Tiap datangnya bulan Maulid, tepatnya perayaan lahirnya pemimpin reformasi yakni Nabi Muhammad saw.

Jutaan umat Islam di Indonesia memperingati tradisi ini dengan beraneka ragam acara dipersiapkan seperti pengajian akbar, lomba tilawah, rebana, azan, sepeda santai, pasar murah, dan khitanan massal. Kegiatan ini sudah jadi tradisi umat Islam di belahan dunia. Namun bagi penganut aliran fundamentalis, kegiatan seperti maulid dianggap Bid'ah.

Padahal perayaan maulid sudah berlangsung sejak Sultan Salahuddin al-Ayyubi, mengadakan mualid dengan kegiatan sayembara penulisan riwayat Nabi beserta puji-pujian bagi Nabi, diikuti seluruh ulama dan sastrawan. Syaikh Ja`far al-Barzanji bin Husin bin Abdul Karim menjadi pemenang pertama dalam kompetisi tersebut, dengan karya kitab Barzanji. Nama asli kitab barzanji adalah lqd Al Jawahir (kalung permata), kitab yang mengisahkan riwayat hidup Nabi Muhammad SAW sejak kecil, remaja, dewasa hingga menerima risalah ke-Rosulan dan kisah perjuangannya.

Belakangan judul kitab itu, disingkat Al Barzanji, lantaran buyut syekh Jafar berasal dari Barzinji, Kurdistan, dalam perkembangan, pembacaan al-Barzanji dilakukan di berbagai kesempatan, misalnya acara cukur rambut bayi (akikah), khitanan dan pernikahan.

Tradisi maulid ini, meningatkan kembali perjuangan nabi, sekaligus membentengi dari serangan aliran-aliran yang ingin memberangus tradisi maulid. Hanya ada satu tokoh yang patut menjadi idola masyarakat yakni Nabi Muhammad saw.

\section{Esensi Berkat}

Masyarakat Tegal memiliki perayaan Maulid yang berbeda dengan daerah lain, mereka rela mengorbankan harta hingga ratusan ribu rupiah. Yang membuat unik adalah orang dewasa, remaja, anak-anak hingga abangan hanyut dalam acara tersebut.

Rumah-rumah penduduk dikunci, biasanya kaum Adam, melaksanakan ritual ini di musholla atau mesjid, kegiatan maulid di mulai setelah salat Isya, sedangkan kaum Hawa di rumah tokoh agama sehabis salat Maghrib. Masyarakat hanyut dalam kesakralan perayaan maulid, seperti yang terlihat di desa Pecabean, Kecamatan Pangkah, Kabupaten Tegal.

Maulid berisi pembacaan kitab Barzanji secara bergantian, dari satu orang ke orang lain. Ketika orang yang tergilir membaca Barzanji, yang lain menyimak. Di tengah-tengah acara ada asrakalan (puji-pujian sholawat) diiringi alat rebana, di ujung acara masyarakat 
menyediakan jajanan pasar dan teh hangat, tiap satu rumah diharuskan mengasih konsumsi, berlaku satu malam hingga 12 hari.

Pucak acara diadakan syukuran biasa orang Tegal menyebut Slamatan, ia (masyarakat) di haruskan membuat berkat semampunya. Berkat pada perayaan maulid berbeda dengan berkat hajatan nikah, khitanan, jika berkat pada hajatan biasa mengunakan besek (tempat menaruh nasi dan lauk pauk), sebaliknya, masyarakat dalam membuat berkat maulid begitu istimewa, tempat berkat adanya pakai panci, wajan (alat pengoreng), kompor minyak, sangku, baskom, dan sebagainya, berisi bahan-bahan sembako, lalu diatasnya ditutupi sapu tangan atau dihiasi pernak-pernik dari kertas, bagi orang kaya akan ditambah sarung, peci atau perlengkapan sholat yang lain.

Tiap keluarga membuat 3 hingga 5 berkat, ada juga yang membuat 200 berkat, itu tergantung pada tingkat ekonomi. Kemudian berkat di kumpulkan di musholla atau mesjid pada malam kelahiran Nabi Muhammad saw yakni tanggal 12 Rabiul Awwal tahun gajah, disebut tahun gajah karena waktu itu, kabah di serang oleh pasukan kafir Quraisy berkendaraan gajah.

Selain itu, pemilik usaha rumahan yakni logam, tekstil yang ada di Tegal juga memanfaatkan momentum ini, untuk mempererat persaudaran antar pemimpin dengan bawahan (pekerja), dengan cara memberikan berkat.

Seiring perkembangan zaman, memperingati maulid dengan menyuguhkan konsumsi dan selamatan mengunakan berkat mulai luntur, lantaran ada sebagian orang yang menginginkan diganti berupa uang.

Dengan uang nantinya bisa digunakan untuk memperbaiki tempat ibadah. Namun, masyarakat tak mau mengubah tradisi ini karena mereka percaya dengan menyuguhkan makanan berbentuk berkat akan memperoleh berkah. Inilah keunikan perayaan maulid di Tegal.

Maulid semata-mata mempertebal kecintaan umat kepada nabi akhir zaman. Esensi berkat mengajari hidup bermasyarakat tanpa membeda-bedakan suku, ras dan agama. Kearifan lokal lokal berpandangan modernisme tidak bisa ditolak karena produk ini sudah menyebar secara global. Namun kedua budaya ini membutuhkan pengelolaan khusus sehingga tidak menimbulkan konflik..

Post on 31-Dec-2015

https://vdocuments.mx/keunikan-perayaan-maulid-nabi-di-tegal.html 